\title{
The impact of progressive cultivation technology on the productivity of coriander on chernozems of the Lower Volga region
}

\author{
Nataliia Nikolaichenko ${ }^{1}$, Nikolai Strizhkov², Zakiulla Azizov², Marina Muraveva $^{3}$, Nataliia Suminova ${ }^{3}$ \\ Saratov State Vavilov Agrarian University, \\ FSBSI "Research Institute of Agriculture of the South-East", \\ Saratov State Vavilov Agrarian University,
}

\begin{abstract}
The data of long-term research on increasing the yield and quality of coriander seeds by selecting the most productive varieties and improving the basic techniques of its cultivation technology are presented. It has been established that the most productive is the Akkord cultivar, which we have bred and released. Biochemical, biological and agrotechnical features of coriander have been studied. High laboratory germination of coriander seeds was revealed $(90.1 \%$ ), and field germination varied from 88.5 93.5\% depending on the cultivation technology and weather conditions. Low growth rates of coriander were revealed at the beginning of germination and before the branching phase. By the budding and flowering phase, the formation of the leaf surface (46.2 thousand $\left.\mathrm{m}^{2} / \mathrm{ha}\right)$ and the accumulation of aboveground green (26.2 t/ha) and dry (3.1 t/ha) biomass reach their peak levels. The maximum yield of coriander seeds was achieved by deep plowing to a depth of $25-27 \mathrm{~cm}$ for the Akkord variety $-1.41 \mathrm{t} / \mathrm{ha}$ versus 1.20 and 1.14 for the Alekseevskii 413 and Svetlyi cultivars. The greatest amount of essential oil was contained in all studied varieties in the browning phase of the central umbels and the smallest one in the period of filling and ripening of seeds. On average, over the years of research (2015-2018), the highest yield of coriander seeds $(1.41 \mathrm{t} / \mathrm{ha})$ was obtained with a skip-row $(30 \mathrm{~cm})$ planting and a seeding rate of 2.0 million viable seeds per hectare. With such a seeding rate and planting method, the maximum content of essential oil $(1.20 \%)$ and fat $(20.1 \%)$ is provided, which is $15.5-24.7 \%$ higher compared to both with a lower seeding rate $(0,5$ million germinating seeds per 1 ha) and higher one ( 2.5 million germinating seeds per 1 ha). The same pattern is observed for other sowing methods - line and wide-row planting.
\end{abstract}

\section{Introduction}

Coriander is cultivated for various economic purposes: as a spice, medicinal and odoriferous crop. Currently, coriander is cultivated in Russia, North America, the Balkans and India. The sowing area of coriander in Russia is about 176 thousand hectares, or about $80 \%$ of all areas of odoriferous plants. Whole coriander fruits are used as a spicy seasoning in the canning, fish and confectionery industries [1]. The bulk of the coriander crop is used to obtain essential and fatty oils $[2,3]$.

With the expansion of the cultivated areas and the improvement of the technology of cultivation of coriander, its yield increased from 8.7-11.0 to 14.5-18.0 $\mathrm{c} / \mathrm{ha}$ at the present time. Coriander, produced in Russia, competed on the foreign market with Moroccan and Indian coriander due to its high oil content. Therefore, it was valued $10-12 \%$ higher against the Moroccan one, which ensured its sales. It is characteristic that its prices remain high both in the domestic and world markets compared to other oil crops. One of the main advantages of coriander is its high economic performance, since it is rightfully considered the most productive early spring odoriferous crop and can provide sustainable yields without high costs for its cultivation [1]. Coriander is also of great agrotechnical importance, being a phytomeliorant. Due to the early sowing period (April), short growing season (up to 90-100 days) and the absence of common pathogens, coriander is a good precursor for most crops, including winter wheat [4].

The big technological advantages of coriander are the summer harvesting time, which reduces the risk of crop loss due to unfavorable weather, as well as resistance to shattering, which allows picking up the mowed windrows after grain crops. If the technology of cultivation of coriander is observed, the net profit can reach 28-30 thousand rubles per 1 hectare.

The few published experimental materials indicate that the main limiting factor in the formation of the yield is insufficient soil moistening with precipitation. Coriander in the conditions of the Lower Volga region is a less-common and insufficiently studied crop and therefore the technology of its cultivation needs to be adjusted taking into account the varietal characteristics and soil and climatic conditions of the region. In the conditions of the region, the selection and comparative assessment of the productivity of different varieties was

\footnotetext{
* Corresponding author: muravmar2007@yandex.ru
} 
not carried out either. In this regard, studies aimed at studying the biology and adaptive resource-saving technology of coriander cultivation are relevant.

The purpose of the study is the formation of highly productive coriander agrophytocenoses based on the investigation of biological characteristics and the development of adaptive techniques for the cultivation of coriander on chernozems of the Lower Volga region.

\section{Research methodology}

Field experiments were carried out in 2015-2018 on the experimental field of FSBSI RosNIISK (Rossorgo). The basic methods of technologies were studied in the following experiments. Experiment No. 1. The productivity of coriander varieties depending on the plowing depth. The experiment on the study of coriander varieties, depending on the plowing depth, was carried out according to the following scheme: 1 - cultivars (factor A): Accord (mid-ripening), Alekseevskii 413 (early ripening), Svetlyi (early ripening) and 2 - plowing depth (factor B): deep ( $25-27 \mathrm{~cm})$ and regular $(20-22$ $\mathrm{cm})$ plowing. Experiment No. 2. Influence of seeding rates and sowing methods on the yield and quality of coriander seeds of the Akkord cultivar. Seeding rates were studied in million units of germinating seeds per 1 ha (Factor A) - $0.5 ; 1.0 ; 1.5 ; 2.0$ and 2.5 with imposition of sowing methods (Factor B) - line $(15 \mathrm{~cm})$, skip-row $(30 \mathrm{~cm})$ and wide-row $(45 \mathrm{~cm})$ planting

The following preparations were used to protect plants from diseases: Titul Duo at doses of $0.35,0.42$ and 0.50 1/ha and Kolosal Pro at doses of $0.45,0.52$ and $0.60 \mathrm{l} / \mathrm{ha}$; from pests - Kinfos in doses of $0.30,0.37$ and 0.451 /ha and Karachara in doses of $0.15,0.17$ and 0.20 1/ha.

The technology of cultivation of coriander was the generally accepted one with the exception of the studied methods [5].

The climate of the region is characterized as sharply continental and arid. The amount of precipitation (hydrothermic coefficient) in wet years $(2016,2017)$ is $1.00-1.45$ and dry years $(2015,2018)$ is $0.50-0.60$. The average annual precipitation is $360-455 \mathrm{~mm}$.

The soil of the experimental site is southern, lowhumus, medium-thick, heavy loamy chernozem. The content of humus (according to Tyurin) is $3.2-4.3 \%$, of mobile phosphorus - $18.2-22.6 \mathrm{mg} / \mathrm{kg}$, of exchangeable potassium (according to Machigin) - 28.0-34.6 mg/100 g of soil. The water-physical properties of the $0-70 \mathrm{~cm}$ layer: density $-1.25-1.36 \mathrm{~g} / \mathrm{cm}^{3}$, the lowest moisture capacity (LMC) $-27.1 \%$, the moisture content of sustained wilting $-12.8 \%$ to the dry mass of the soil.

Field experiments were carried out in 4 replicates using a randomized method. The record plot was $100 \mathrm{~m}^{2}$, and the sowing area was $150 \mathrm{~m}^{2}$. Crop record was carried out by continuous harvesting by direct combining with a Sampo Rostov 2010 combine harvester.

The organization and conduct of field experiments and research was carried out according to generally accepted methods and methodological developments of B.A. Dospekhova, B.M. Smirnov [5, 6, 7]. The content of NPK in the soil was determined by taking mixed soil samples from the $0-40 \mathrm{~cm}$ layer, of nitrate nitrogen according to Grandval-Lazhoux method, of mobile phosphorus and exchangeable potassium - according to Machigin in the modification of the Central Research Institute of Agrochemical Services for Agriculture. The chemical composition of the seeds was determined according to GOST 10842-91 and the nutritional value according to GOST 108-42-76. The quality indicators of seeds were determined according to the relevant standards: seed moisture (drying method) according to GOST 12041-66, the mass of 1000 seeds according to GOST 10802-76. The experimental data were statistically processed by the method of dispersion and correlation analyzes [7].

\section{Results and discussion}

Botanical features and chemical composition. Coriander (Coriandrum Sativum L.) is an annual plant in the Umbelliferae family. It has a ribbed, highly branched stem with a height of 50 to $150 \mathrm{~cm}$ and a well-developed tap root system. The leaves are pinnate. Inflorescences are a compound umbel. The flowers are usually white or pale pink, but they can be purple or yellow. The fruit consists of two pieces. In the walls of the fruitlets, under the seed coat, there are two tubules filled with essential oil $[8,9]$. Coriander is resistant to soil and air drought.

The Akkord cultivar we have bred is distinguished by a high content of essential $(0.98 \%)$ and fatty $(20.1 \%)$ oils, which is $8.1 \%$ and $12.5 \%$ higher than the Alekseevskii 413 and Svetlyi cultivars, respectively.

Studies carried out in the Crimea made it possible to establish that the maximum content of essential oil $(2.81 \%)$ falls on the stage of ovary formation [8]. In the phase of milky ripeness, the essential oil content was $2.32 \%$, of wax ripeness $-0.37 \%$, of full ripeness - only $0.21 \%$. At the factory, it is extracted by steam distillation. There is less essential oil in coriander fruits than other chemical constituents (Table 1).

Based on the experimental data of E. V. Vulf (1937), came to the conclusion that the synthesis of oil and nitrogenous substances in coriander proceeds most intensively from the moment of ovary formation to flowering [10].

Similar data were obtained in our experiments to study the dynamics of the accumulation of essential oil by different varieties of coriander (Table 2).

Most of the essential oil was contained in seeds at the beginning of the browning phase of the central umbels (see Table 2). Among the studied cultivars, the maximum percentage of essential oil from $0.90 \%$ to $0.71 \%$ was found in the Akkord cultivar versus $0.69 \%$ $0.63 \%$ in the Alekseevskii 413 cultivar and $0.66 \%$ $0.58 \%$ in the Svetlyi cultivar. That is, the largest output of essential oil can be obtained during the period of maximum seed yield, which in production can be realized when $75 \%$ of all fruits ripen. 
Table 1. Content of various chemical constituents in coriander (in percent).

\begin{tabular}{|l|l|}
\hline Plant components & Percentage of oven-dry weight \\
\hline Water & 11,4 \\
\hline Essential oil & 0,84 \\
\hline Nitrogenous substances & 19,9 \\
\hline Fat & 19,0 \\
\hline Raw fiber & 30,62 \\
\hline Ash & 4,92 \\
\hline Sugar & 0,19 \\
\hline
\end{tabular}

Table 2. Content of essential oil in seeds of various coriander cultivars during seed ripening (percentage of oven-dry weight), average for 2015-2018.

\begin{tabular}{|l|l|l|l|}
\hline Vegetation phase & \multicolumn{3}{|l|}{ Cultivars } \\
\cline { 2 - 4 } & Akkord & $\begin{array}{l}\text { Alekseevskii } \\
413\end{array}$ & Svetlyi \\
\hline $\begin{array}{l}\text { The beginning of } \\
\text { browning of the } \\
\text { central umbels }\end{array}$ & 0,90 & 0,69 & 0,66 \\
\hline $\begin{array}{l}\text { Browning of the } \\
\text { central umbels in } \\
50 \% \text { of plants }\end{array}$ & 0,80 & 0,72 & 0,60 \\
\hline $\begin{array}{l}\text { Browning of the } \\
\text { central umbels in 75 } \\
\% \text { of plants }\end{array}$ & 0,79 & 0,71 & 0,60 \\
\hline $\begin{array}{l}\text { Browning of side } \\
\text { umbels }\end{array}$ & 0,71 & 0,63 & 0,58 \\
\hline
\end{tabular}

Characteristics of growth and development. Large coriander seeds with a diameter of 3-4 $\mathrm{mm}$ and a weight of 1000 seeds up to $9.01 \mathrm{~g}$ had a germination energy of $73.5 \%$ and a laboratory germination rate of up to $93.5 \%$, which is $6.0-8.0 \%$ higher than with smaller seeds with a diameter of 2-3 mm and a weight of 1000 seeds of 6.61 g. Field germination on average over the years of research was $80.5-87.1 \%$. In addition, coriander is characterized by slow growth at the beginning of the growing season $-0.8 \mathrm{~mm}$ per day. Its growth rate increases in subsequent phases and by the flowering phase is $7.2 \mathrm{~cm}$. The duration of the period from sowing to germination reaches $16-20$ days, from germination to flowering - 50-55 days, from flowering to ripening - 3036 days, and the entire vegetation perios - 98-106 days
Leaf apparatus formation. The area of the leaf apparatus depends on vegetation phase, plant density and sowing method. The leaf surface (LS) and photosynthetic potential (FP) increased from germination to the flowering phase and reached an average of 46.2 thousand $\mathrm{m}^{2} / \mathrm{ha}$ and 1621.5 thousand $\mathrm{m}^{2} /$ ha per day in 2015-2018, respectively. Coriander developed a maximum leaf surface of 50.1 thousand $\mathrm{m}^{2} /$ ha in the flowering phase with the skip-row method $(30 \mathrm{~cm})$ and a seeding rate of 2.0 million germinating seeds per 1 ha, which is 15.0 and $22.0 \%$ higher compared to line $(15 \mathrm{~cm})$ and wide-row $(45 \mathrm{~cm})$ sowing methods.

Dynamics of green and dry biomass accumulation. The accumulation of green and dry biomass proceeded similarly to the formation of the leaf apparatus. At the beginning of vegetation, the rates of biomass accumulation were low. Their maximum values are noted at the flowering phase - the beginning of fruit formation, reaching a value of 21.8-26.2 $\mathrm{t} / \mathrm{ha}$, depending on the seeding rate and the sowing method. Skip-row sowing with a seeding rate of 2.0 million viable seeds per hectare provided the accumulation of $26.2 \mathrm{t} / \mathrm{ha}$ of green and $4.30 \mathrm{t} / \mathrm{ha}$ of dry biomass. Both an increase and a decrease in the seeding rate in comparison with the optimal 2.0 million germinating seeds per hectare led to a decrease in the rate of accumulation and volume of biomass.

More significant differences in terms of leaf surface and the dynamics of green and dry biomass accumulation were found between cultivars. The maximum LS and FP were in the Akkord cultivar - 46.2 thousand $\mathrm{m}^{2} / \mathrm{ha}$ and 1722.6 thousand $\mathrm{m}^{2} / \mathrm{ha}$ per day, respectively, and in the Alekseevskii 413 and Svetlyi cultivars - by $12.2 \%$ and $16.2 \%$ lower. The same changes were observed in the formation of green and dry biomass, which was maximum in the Akkord cultivar, amounting to $27.4 \mathrm{t} / \mathrm{ha}$ and $4.51 \mathrm{t} / \mathrm{ha}$, and in the Alekseevskii 413 and Svetlyi cultivars - 22.6 and 3.41 t/ha. - 20.9 and 3.10 t/ha, respectively.

Impact of plowing depth on the productivity of different coriander cultivars. The high rates of formation of aboveground biomass, shoot and fruit formation in the Akkord cultivar also ensured a higher seed yield, an increased content of essential and fatty oils in comparison with other cultivars, sown with a seeding rate of 2.0 million viable seeds per hectare (tables 3,4 ).

Table 3. Productivity of coriander cultivars depending on plowing depth, average for 2015-2018.

\begin{tabular}{|c|c|c|c|c|c|c|c|c|c|}
\hline \multirow[b]{2}{*}{ Cultivars } & \multirow[b]{2}{*}{$\begin{array}{l}\text { Plowing } \\
\text { depth, cm }\end{array}$} & \multirow{2}{*}{$\begin{array}{l}\text { Field } \\
\text { germination } \\
\text { of seeds, \% }\end{array}$} & \multirow[b]{2}{*}{$\begin{array}{l}\text { Plant } \\
\text { livability, } \\
\%\end{array}$} & \multirow{2}{*}{$\begin{array}{l}\text { Plant } \\
\text { height, } \\
\mathrm{cm}\end{array}$} & \multirow{2}{*}{$\begin{array}{l}\text { Seed } \\
\text { yield, } \\
\text { t/ha }\end{array}$} & \multirow{2}{*}{$\begin{array}{l}\text { Seed } \\
\text { weight } \\
\text { per } 1 \\
\text { plant, g }\end{array}$} & \multirow[b]{2}{*}{$\begin{array}{l}\text { Weight } \\
\text { of } 1000 \\
\text { seeds, } g\end{array}$} & \multicolumn{2}{|c|}{ Oil content, \% } \\
\hline & & & & & & & & Essential & Fatty \\
\hline \multirow[t]{2}{*}{ Akkord } & $25-27$ & 92,3 & 93,5 & 52,5 & 1,41 & 0,98 & 6,65 & 0,91 & 19,4 \\
\hline & $20-22$ & 90,0 & 89,1 & 50,2 & 1,11 & 0,91 & 6,00 & 0,80 & 18,6 \\
\hline \multirow{2}{*}{$\begin{array}{l}\text { Alekseevskii } \\
413\end{array}$} & $25-27$ & 90,1 & 87,0 & 53,9 & 1,20 & 0,90 & 5,91 & 0,79 & 18,9 \\
\hline & $20-22$ & 84,1 & 87,5 & 46,2 & 0,95 & 0,83 & 5,63 & 0,75 & 18,1 \\
\hline \multirow[t]{2}{*}{ Svetlyi } & $25-27$ & 89,1 & 86,8 & 50,4 & 1,14 & 0,88 & 5,70 & 0,75 & 18,3 \\
\hline & $20-22$ & 82,0 & 83,7 & 45,8 & 0,89 & 0,81 & 5,54 & 0,72 & 17,8 \\
\hline
\end{tabular}


Table 4. Productivity of coriander cultivars depending on plowing depth, average for 2015-2018.

\begin{tabular}{|c|c|c|c|c|c|c|}
\hline \multirow{2}{*}{$\begin{array}{l}\text { Cultivars } \\
\text { (Factor A) }\end{array}$} & \multirow{2}{*}{$\begin{array}{l}\text { Plowing depth, cm } \\
\text { (Factor B) }\end{array}$} & \multicolumn{5}{|c|}{ Seed yield, t/ha } \\
\hline & & 2015 & 2016 & 2017 & 2018 & Average \\
\hline \multirow[t]{2}{*}{ Akkord } & $20-22$ & 1,00 & 0,91 & 1,22 & 1,31 & 1,11 \\
\hline & $25-27$ & 0,88 & 1,18 & 1,54 & 1,62 & 1,41 \\
\hline \multirow{2}{*}{ Alekseevskii 413} & $20-22$ & 0,74 & 0,72 & 1,18 & 1,16 & 0,95 \\
\hline & $25-27$ & 1,00 & 1,04 & 1,36 & 1,40 & 1,20 \\
\hline \multirow[t]{2}{*}{ Svetlyi } & $20-22$ & 0,58 & 0,79 & 1,20 & 1,09 & 0,89 \\
\hline & $25-27$ & 1,00 & 0,96 & 1,32 & 1,28 & 1,14 \\
\hline \multicolumn{2}{|l|}{ LSD05 Factor A } & 0,03 & 0,03 & 0,05 & 0,06 & \\
\hline \multicolumn{2}{|l|}{ Factor B } & 0,04 & 0,03 & 0,03 & 0,04 & \\
\hline \multicolumn{2}{|l|}{ Factor AB } & 0,03 & 0,02 & 0,04 & 0,05 & \\
\hline
\end{tabular}

On average, over the years of research, the maximum seed yield of the Akkord cultivar was obtained by deep plowing $(25-27 \mathrm{~cm})$ and amounted to $1.41 \mathrm{t} / \mathrm{ha}$ versus 1.20 and $1.14 \mathrm{t} / \mathrm{ha}$ for the Alekseevskii 413 and Svetlyi cultivars, which is $15,5 \%$ and $19.1 \%$ lower in comparison with the above-mentioned cultivar (see table 4). The increase in the productivity of the Akkord cultivar was achieved due to the higher mass of seeds per plant, which amounted to $0.98 \mathrm{~g}$, and weight of 1000 seeds - $0.65 \mathrm{~g}$, which is $12-14 \%$ higher compared to other cultivars. The Accord cultivar has a high content of essential oil $(0.91 \%)$ and fat $(13.4 \%)$. In other cultivars, these indicators are lower $-0.79 \%$ and $0.75 \%$ and $18.9 \%$ and $17.8 \%$. The seed yield of all the studied cultivars with conventional plowing $(20-22 \mathrm{~cm})$ was $18-21 \%$ lower compared to deep plowing.

The content of essential and fatty oil is lower with conventional plowing and amounted to $0.80 \%$ and $18.6 \%$, respectively, versus $0.91 \%$ and $19.4 \%$ for deep plowing. The plowing depth did not significantly affect the essential oil content.

Many researchers confirm the important function of plant residues in regulating soil fertility and creating conditions for plant growth and development [11, 12].

As a phytomeliorant, coriander is a good precursor for other crops $[9,13,14]$. At present, the transition to minimal tillage does not always lead to an increase in effective fertility, but it is justified in relation to the preservation of potential fertility associated with a lower mineralization of organic matter, a decrease in the emission of one of the greenhouse gases $\mathrm{CO} 2$ into the atmosphere and the effect, in this connection, on the change in the global climate $[15,16,17]$.

The results of earlier studies at the All-Union Institute of Plant Growing and other scientific institutions also indicate that the highest yields of coriander are formed by deep plowing on fertile chernozems and such predecessors as fallow, winter crops and soil overturning [18, 19, 20, 21, 22].

Table 5. Impact of sowing methods and seeding rates on the yield and quality of coriander seeds.

\begin{tabular}{|c|c|c|c|c|c|c|c|c|c|}
\hline \multirow{4}{*}{$\begin{array}{l}\text { Seeding rates, mln. germinating } \\
\text { seeds per hectare (factor A) }\end{array}$} & \multirow{3}{*}{\multicolumn{2}{|c|}{$\begin{array}{l}\text { Way of sowing and row } \\
\text { spacing (factor B) }\end{array}$}} & \multicolumn{5}{|c|}{ Seed yield, $t /$ ha } & \multicolumn{2}{|c|}{$\begin{array}{l}\text { Content, in } \\
\% \text { of oven-dry } \\
\text { substance }\end{array}$} \\
\hline & & & \multicolumn{4}{|c|}{ Years } & \multirow{3}{*}{$\begin{array}{l}\text { Average, } \\
2015-2018\end{array}$} & $\begin{array}{l}\text { Average, } \\
2018\end{array}$ & 2015- \\
\hline & & & \multicolumn{2}{|l|}{ dry } & \multicolumn{2}{|l|}{ wet } & & \multirow{2}{*}{ 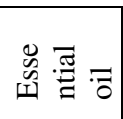 } & \multirow[b]{2}{*}{ है } \\
\hline & name & $\mathrm{cm}$ & 2015 & 2016 & 2017 & 2018 & & & \\
\hline \multirow{3}{*}{0,5} & Line & 15 & 0,71 & 0,61 & 1,21 & 1,11 & 0,91 & 1,08 & 19,8 \\
\hline & Skip-row & 30 & 0,60 & 0,66 & 0,92 & 0,86 & 0,76 & 1,09 & 19,9 \\
\hline & Wide-row & 60 & 0,40 & 0,50 & 0,70 & 0,80 & 0,60 & 1,10 & 20,2 \\
\hline \multirow{3}{*}{1,0} & Line & 15 & 0,90 & 0,99 & 1,19 & 1,28 & 1,09 & 1,19 & 19,9 \\
\hline & Skip-row & 30 & 0,75 & 0,69 & 1,11 & 1,15 & 0,90 & 1,20 & 20,0 \\
\hline & Wide-row & 60 & 0,59 & 0,62 & 0,98 & 0,91 & 0,80 & 1,20 & 19,8 \\
\hline \multirow{3}{*}{1,5} & Line & 15 & 1,18 & 1,08 & 1,31 & 1,20 & 1,19 & 1,19 & 20,8 \\
\hline & Skip-row & 30 & 0,71 & 0,85 & 1,16 & 1,31 & 1,01 & 1,20 & 20,7 \\
\hline & Wide-row & 60 & 0,76 & 0,65 & 1,11 & 1,00 & 0,88 & 1,18 & 20,6 \\
\hline \multirow{3}{*}{2,0} & Line & 15 & 1,27 & 1,22 & 1,60 & 1,55 & 1,41 & 1,20 & 20,1 \\
\hline & Skip-row & 30 & 1,00 & 1,05 & 1,40 & 1,35 & 1,20 & 1,18 & 20,1 \\
\hline & Wide-row & 60 & 0,72 & 0,80 & 1,30 & 1,22 & 1,01 & 1,09 & 19,8 \\
\hline \multirow{3}{*}{2,5} & Line & 15 & 1,08 & 1,06 & 1,48 & 1,50 & 1,28 & 1,06 & 18,9 \\
\hline & Skip-row & 30 & 0,98 & 0,92 & 1,38 & 1,32 & 1,12 & 0,99 & 18,8 \\
\hline & Wide-row & 60 & 0,70 & 0,77 & 1,22 & 1,15 & 0,92 & 0,98 & 19,0 \\
\hline \multicolumn{2}{|l|}{ LSD05 Factor A } & & 0,04 & 0,06 & 0,10 & 0,11 & 0,10 & & \\
\hline \multicolumn{2}{|l|}{ Factor B } & & 0,12 & 0,14 & 0,20 & 0,19 & 0,20 & & \\
\hline \multicolumn{2}{|l|}{ Factor AB } & & 0,03 & 0,04 & 0,05 & 0,05 & 0,07 & & \\
\hline
\end{tabular}


Thus, the highest seed yield (1.41 t/ha) with the maximum content of essential $(0.91 \%)$ and fatty $(19.4 \%)$ oils is ensured when sowing the Akkord cultivar and using plowing to a depth of $25-27 \mathrm{~cm}$, which is $15.5 \%$ $19.1 \%$ higher compared to the Alekseevskii and Svetly cultivars and $5.0 \%-9.5 \%$ higher compared to conventional plowing. This confirms that varietal characteristics had a greater impact on the essential oil content than plowing depth.

Yield and quality of coriander seeds, depending on the seeding rate and sowing method. The results of our long-term studies allow us to establish a pattern of a significant effect of the seeding rate on the yield and quality of coriander seeds (Fig. 1, Table 5). As the seeding rate increases, the yield of coriander seeds increases. This increase was noted with an increase in the seeding rate from 0.5 to 2.0 millions of germinating seeds per hectare. With a further increase in the seeding rate, the yield of coriander seeds decreased. This effect of the seeding rate on seed yield is observed for all sowing methods (see Table 5).

The seeding rate had the same effect on the essential oil content. This is due to a decrease in the photosynthetic activity of plants and their livability in thickened crops. Thus, in sparse crops (0.5 million germinating seeds per hectare), the plant density was close to the specified one and their livability was 88$92 \%$, then in thickened crops (2.5 million germinating seeds per hectare) $-80-87 \%$. On average, over the years of research, the highest seed yield (1.41 t/ha) was achieved at a seeding rate of 2.0 million viable seeds per hectare and the line sowing method, which is $0.5 \mathrm{t} / \mathrm{ha}$ higher than the seeding rate of 0,5 million germinating seeds per hectare.
The content of essential oil (1.24\%) also increased with an increase in the seeding rate and peaked at 2.0 million germinating seeds per hectare, which is $12-15 \%$ higher compared to 0.5 to 1.5 million germinating seeds per hectare. An increase in the seeding rate of more than 2.0 million germinating seeds per hectare led to a decrease in the content of essential oil by $11-14 \%$. Weather conditions had a more significant impact on the essential oil content. In wet years of 2017 and 2018, the essential oil content was $18-23 \%$ higher compared to dry 2015 and 2016 years.

The seeding rates and sowing methods did not have a noticeable effect on the fat content, only a tendency to increase it is observed. As for the influence of weather conditions, the following is noted by us: in wet years, the content of fatty oil increased to $20.1-21.8 \%$, and in dry years it decreased to $16.0-17.5 \%$.

The relationship between yield and seeding rate is reflected by the following equation $\mathrm{y}=-0.18 \mathrm{x}^{3}+$ $0.6671 x^{2}-0.4214 x+0.986$, where the coefficient of determination between these indicators was 0.9554 (Fig. $1)$.

Seed weight per plant decreased with an increase in the seeding rate. Thus, the maximum seed weight per plant $(1.48 \mathrm{~g})$ was in the variant with a seeding rate of 0.5 million, which is $54 \%$ more compared to the seeding rate of 2.5 million germinating seeds per 1 ha. However, a decrease in the mass of seeds per plant in thickened crops was compensated by an increase in the number of plants. This provided an increase in seed yield in crops with increased plant density [23]. These data are confirmed by studies of I.D. Serov [20] conducted at the All-Russian Institute of Plants and in Tajikistan [24].

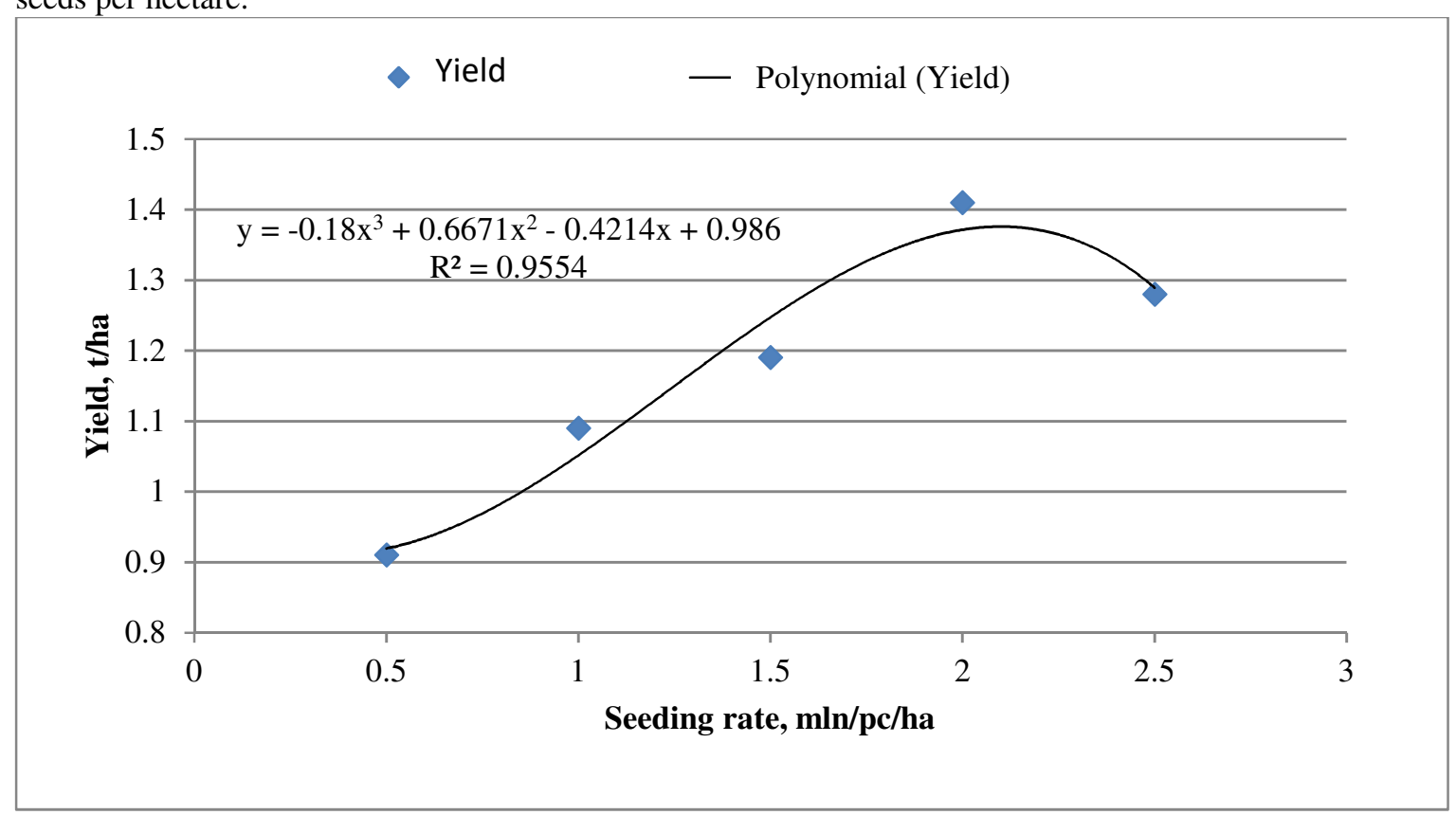

Fig. 1. Dependence of the yield of coriander seeds on the seeding rate, average for 2015-2018.

The influence of plant protection products on the yield and quality of coriander seeds.

To obtain environmentally safe products in an integrated plant protection system, biological products are also used along with chemicals. However, their share of the total volume of pesticide use to protect field crops from diseases and pests is only a few percent [25]. Currently, plant growing uses mainly chemical plant 
protection products. In our experiments, we studied chemical preparations in the fight against beet webworm, brown rust and powdery mildew.

The conducted studies established that coriander is resistant to diseases and pests, which is also confirmed in the experiments of other researchers in the conditions of the Lower Volga region [26, 27, 28]. In severely arid years, damage by the beet webworm was noted in the phases of umbel formation and flowering. In a field experiment in the fight against the beet webworm, the effectiveness of various doses of Kinfos and Karachara preparations in the budding phase was studied (Table 6).

As a result of the research, it was found that the most effective preparation was Kinfos at a dose of $0.45 \mathrm{l} / \mathrm{ha}$, with the use of which the number of caterpillars of the beet webworm decreased by $88.6 \%$, which contributed to an increase in yield by $0.28 \mathrm{t} / \mathrm{ha}$ or $33.3 \%$ compared to control.

Damage by diseases (powdery mildew, brown rust) was observed only in wet years. The preparations Titul Duo and Kolosal Pro were used against rust during the growing season. The results obtained allow us to conclude that the tested preparations showed a high biological efficiency of their use from $94 \%$ to $96 \%$. At the same time, the best dose of Title Duo was $0.50 \mathrm{l} / \mathrm{ha}$, of Kolosal Pro - 0.60 1/ha. The use of Titul Duo and Kolosal Pro made it possible to obtain 1.20 and $1.12 \mathrm{t} / \mathrm{ha}$ of seeds, respectively, which is $16.0 \%$ and $12.0 \%$ higher compared to control.

Table 6. Efficacy of various doses of preparations against beet webworm caterpillars.

\begin{tabular}{|c|c|c|c|c|c|c|}
\hline \multirow[b]{2}{*}{ Preparations } & \multirow{2}{*}{$\begin{array}{l}\text { Doses, } \\
\text { 1/ha }\end{array}$} & \multirow{2}{*}{$\begin{array}{l}\text { Pest } \\
\text { population } \\
\text { per } \mathrm{m}^{2}\end{array}$} & \multirow[t]{2}{*}{ Biological efficacy, $\%$} & \multirow[t]{2}{*}{ Seed yield, t/ha } & \multicolumn{2}{|c|}{ Seed yield increase } \\
\hline & & & & & t/ha & $\%$ \\
\hline $\begin{array}{l}\text { Control, without } \\
\text { treatment }\end{array}$ & 0 & 14,0 & 0 & 0,84 & - & - \\
\hline \multirow[t]{3}{*}{ Kinfos } & 0,30 & 5,8 & 58,5 & 0,92 & 0,08 & 9,5 \\
\hline & 0,37 & 3,1 & 78,0 & 1,06 & 0,22 & 26,2 \\
\hline & 0,45 & 1,6 & 88,6 & 1,12 & 0,28 & 33,3 \\
\hline \multirow[t]{3}{*}{ Karachara } & 0,15 & 6,3 & 55,0 & 0,90 & 0,06 & 7,1 \\
\hline & 0,17 & 4,0 & 71,4 & 1,00 & 0,16 & 19,0 \\
\hline & 0,20 & 2,1 & 85,0 & 1,08 & 0,24 & 28,6 \\
\hline
\end{tabular}

\section{Conclusions}

1. The biological feature of coriander is its high laboratory germination of seeds (93.5\%). Field germination with an increase in the seeding rate from 0.5 million to 2.5 million germinating seeds per hectare decreased from $87.6 \%$ to $80.5 \%$, and the livability of plants increased from $83.7 \%$ to $93.5 \%$. The maximum field germination $(86.3 \%)$ and livability $(93.5 \%)$ were in the Akkord cultivar with deep plowing by $25-27 \mathrm{~cm}$, which is $3.0-4.5 \%$ higher compared to conventional plowing by $20-22 \mathrm{~cm}$. This pattern is also established for Alekseevskii 413 and Svetlyi cultivars.

2. The maximum accumulation of green dry biomass (27.4 and $4.51 \mathrm{t} / \mathrm{ha})$, leaf surface (46.2 thousand $\mathrm{m}^{2} / \mathrm{ha}$ ) and photosynthetic potential (1722.6 thousand $\mathrm{m}^{2} /$ ha*day) is observed in the Akkord cultivar with the use of deep plowing by $25-27 \mathrm{~cm}$, which is $12-16 \%$ higher compared to conventional plowing by $20-22 \mathrm{~cm}$. ) Coriander developed a maximum leaf area of 50.1 thousand $\mathrm{m}^{2} / \mathrm{ha}$ in the flowering phase with the line sowing method $(15 \mathrm{~cm})$ and a seeding rate of 2.0 million viable seeds per 1 ha, which is $11.5 \%$ and $14.5 \%$ higher compared to both higher and lower seeding rates. This pattern is also preserved for other sowing methods.

3. The high rates of growth and development of the Akkord cultivar with deep plowing by $25-27 \mathrm{~cm}$ ensured the maximum seed yield (1.41 t/ha) and the content of essential oil $(0.91 \%)$ and fat $(18.6 \%)$ in comparison with cultivars Alekseevskii 413 and
Svetlyi, their parameters were lower and amounted to 0.90 and 0.88 tons of seeds per hectare, $0.79 \%$ and $0.75 \%$ of essential oil, $18.1 \%$ and $17.8 \%$ of fatty oil, respectively.

4. The optimal conditions for shaping of the productivity of coriander are formed at a seeding rate of 2.0 million germinating seeds per hectare and the line method of sowing. In such a way, $1.41 \mathrm{t} / \mathrm{ha}$ of seeds were obtained, which is $50 \%$ and $11 \%$ higher compared to both a lower ( 0.5 million pieces per 1 ha) and a higher seeding rate $(2.5$ million pieces per hectare). This effect of the seeding rate on seed yield is observed for all sowing methods. The seeding rates and sowing methods had less effect on the essential oil content than on the seed yield. For all sowing methods, with an increase in the seeding rate, there is a slight decrease in the content of essential oil, which amounted to $1.08-1.10 \%$ at a seeding rate of 0.5 million pieces per 1 ha and $1.06-0.98 \%$ at a seeding rate of 2.5 million pieces per 1 hectare.

5. The best preparation in the fight against beet webworm is Kinfos at a dose of $0.451 /$ ha, which ensured the $88.6 \%$ biological effectiveness of its use and the maximum increase in seed yield by $33.3 \%$ compared to the control.

\section{References}

1. M.N. Khudenko Features of growing coriander in the Volga region. (Saratov: SSAU Publishing House, 2012). 
2. I. D. Serov, Coriander in industry and its cultivation. (Saratov: Saratov Regional Publishing House, 1947).

3. E. Miiller Heilpflanzen in Garten gezogen. (Grazstuttgart, 1982).

4. I. S. Palamar, A. A. Khotina. Coriander (Moscow: Selkhozizdat, 1957).

5. Research Institute of Agriculture of the SouthEast Recommendations on the methodology for conducting observations and research in the field experiment (Saratov: Volga book. publishing house, 1963)

6. Methodology for state variety testing of agricultural crops. (Moscow: Kolos, 1971)

7. B. A. Dospekhov Field experiment technique (with the basics of statistical processing of research results) (Moscow: Agropromizdat, 1985)

8. N.S. Palamar (Ed.) Essential oil crops of the middle zone of the USSR (mint, coriander, anise, cumin). (Moscow: Gosizdatselkhozlit, Selkhozgiz, 1953)

9. A. A. Khotin, G. T. Shulgin (Eds.) Essential oil crops. (Moscow: Publishing house of agricultural literature, magazines and posters, 1963).

10. E.V. Vulf, Essential oil plants, their culture and essential oils (Moscow-Leningrad, 1937).

11. J.A. Delgado J. Soil. Water Conserv., 65 (5), 111-116, (2010)

12. H. Blanco-Canqui, R. Lal Critic. Rev. Plant Sci. Special issue: Carbon sequestration, 28. 1. 3, 139-163, (2009).

13. E.A. Stoletova. Coriander (Institute of Plant Growing, Leningrad, 1966).

14. A. A. Khotin, Agrobiology, 2, 72-80, (1969).

15. C.C. Passianoto, T. Ahrens, B.J. Feigl, P.A. Steudler, J.B. do Carmo, J.M. Mellilo Biol. Fertil. Soils, 38, 200-208, (2003)

16. S. Hermle, T. Anken, J. Leifeld, P. Weisskopf Soil Tillage Res., 98, 94-105, (2008).

17. B.D. Soane, B.C. Ball, J. Arvidsson, G. Basch, F. Moreno, J. Roger-Estrade Soil Tillage Res. 118б 66-87, (2012).

18. Stoletova E.A. Coriander (Leningrad: VASKHNIL, 1931).

19. Mazepov, I.S. Dragonhead, coriander. Their development and processing in the conditions of the Middle Volga region (Sredne-Volzhskaya Regional office "OMPK", 1931).

20. I. D .Serov, Coriander (Saratov: Privolzhskoe book publishing house, 1957)

21. J.T. Medler J. Econ. Entomol.,. 5, 47, (1955)

22. J.T. Medler, G.N. Brooks J. Econ. Entomol., 3, 50, (1957)

23. G.T. Shulgin, A short guide to essential oil сropsю (Moscow, 1979).

24. P.P. Chapaev, K. D. Rachkova. Scientific notes of the Tajik Institute, 6 (1), 38-49, (1969).

25. S. Gasic, and B. Tanovic Pesticides and Phylomedicine, 28 (2), 97-102, (2013).

26. S.E. Kamenchenko, N. I. Strizhkov, T. V.
Naumova Agriculture, 1, 41-43, (2012).

27. S.E. Kamenchenko, N.I. Strizhkov, T.V. Naumova Agriculture, 3, 37-39, (2013).

28. T. Wetzel, Integrierter Pflanzschutz und Agroecosysteme. Halle (Vogtl., 1995) 